Article

\title{
Gum Arabic-Magnetite Nanocomposite as an Eco-Friendly Adsorbent for Removal of Lead(II) Ions from Aqueous Solutions: Equilibrium, Kinetic and Thermodynamic Studies
}

\author{
Ismat H. Ali 1,*(D), Mutasem Z. Bani-Fwaz ${ }^{1} \mathbb{D}$, Adel A. El-Zahhar 1,2 ${ }^{\mathbb{D}}$, Riadh Marzouki 1,3 ${ }^{\mathbb{D}}$, Mosbah Jemmali $^{4,5} \mathbb{D}$ \\ and Sara M. Ebraheem ${ }^{6}$ \\ 1 Department of Chemistry, College of Science, King Khalid University, Abha 61413, Saudi Arabia; \\ mbanifawaz@kku.edu.sa (M.Z.B.-F.); elzahhar@kku.edu.sa (A.A.E.-Z.); rmarzouki@kku.edu.sa (R.M.) \\ 2 Department of Nuclear Chemistry, Egyptian Atomic Energy Authority, Cairo 13759, Egypt \\ 3 Laboratory of Materials, Crystal Chemistry and Applied Thermodynamics, LR15ES01, \\ Faculty of Sciences of Tunis, University of Tunis El Manar, Tunis 1608, Tunisia \\ 4 Faculty of Science, University of Sfax, LSME, BP1171, Sfax 3018, Tunisia; jmosbah@yahoo.fr \\ 5 Department of Chemistry, College of Science and Arts, Ar-Rass, Qassim University, P.O. Box 53, \\ Buraydah 51921, Saudi Arabia \\ 6 Department of Chemistry, College of Science and Arts, King Khalid University, \\ Saratabida 61914, Saudi Arabia; saraabdulgader7@gmail.com \\ * Correspondence: ismathassanali@gmail.com
}

check for updates

Citation: Ali, I.H.; Bani-Fwaz, M.Z.; El-Zahhar, A.A.; Marzouki, R.; Jemmali, M.; Ebraheem, S.M. Gum Arabic-Magnetite Nanocomposite as an Eco-Friendly Adsorbent for Removal of Lead(II) Ions from Aqueous Solutions: Equilibrium, Kinetic and Thermodynamic Studies. Separations 2021, 8, 224. https:// doi.org/10.3390/separations8110224

Academic Editor: Attilio Naccarato

Received: 17 September 2021

Accepted: 12 November 2021

Published: 18 November 2021

Publisher's Note: MDPI stays neutral with regard to jurisdictional claims in published maps and institutional affiliations.

Copyright: (c) 2021 by the authors. Licensee MDPI, Basel, Switzerland. This article is an open access article distributed under the terms and conditions of the Creative Commons Attribution (CC BY) license (https:/ / creativecommons.org/licenses/by/ $4.0 /)$.

Abstract: In this study, a gum Arabic-magnetite nanocomposite (GA/MNPs) was synthesized using the solution method. The prepared nanocomposite was characterized by Fourier transform infrared spectroscopy (FTIR), scanning electron microscopy (SEM), transmission electron microscopy (TEM), X-ray diffraction (XRD), vibrating sample magnetometer (VSM), and thermogravimetric analysis (TGA). The prepared composite was evaluated for the adsorption of lead(II) ions from aqueous solutions. The controlling factors such as $\mathrm{pH}$, contact time, adsorbent dose, initial ion concentration, and temperature were investigated. The optimum adsorption conditions were found to be $0.3 \mathrm{~g} / 50 \mathrm{~mL}, \mathrm{pH}=6.00$, and contact time of $30 \mathrm{~min}$. The experimental data well fitted the pseudo-second-order kinetic model and the Langmuir isotherm model. The maximum adsorption capacity was determined as $50.5 \mathrm{mg} / \mathrm{g}$. Thermodynamic parameters were calculated postulating an endothermic and spontaneous process and a physio-sorption pathway.

Keywords: adsorption; gum Arabic; magnetite; nano-composite; lead(II)

\section{Introduction}

There has been growing anxiety regarding public health and ecological contamination problems related to the presence of heavy metals. The causes of accumulation of heavy metals in soil and water have increased intensely to involve agriculture, the industrial sector, mining, drug manufacture, and many other activities [1]. Amongst the heavy metals that can potentially lead to severe health issues are $\mathrm{Pb}, \mathrm{Cd}, \mathrm{As}, \mathrm{Cr}$, and $\mathrm{Hg}$, and hence have received special attention [2]. One of the major sources of heavy metals in drinking and wastewater are household chemicals and industrial release. Heavy metals in all types of water are typically known to exist as inorganic complexes.

Several procedures for heavy metal removal from water have been established. Among these are adsorption, ion exchange, electrocoagulation, ion-exchange, and precipitation [3-5]. Adsorption is considered one of the most important techniques because it is a low-cost, effective, and simple technique [6]. One of the most toxic heavy metals, lead, has drawn the most concern and attention, since it is extremely poisonous and can cause significant problems to human health [2,7-9]. Lead is usually present in two oxidation states of +2 and +4 . The most widespread and concerning species of lead is $\mathrm{Pb}^{2+}[10]$. 
A wide spectrum of adsorbents have been reported in the literature for the removal of heavy metals from wastewater. Among these, composites are promising systems for the removal of heavy metals from water. Composites usually have large surface areas that increase their efficiency [11]. GA is a natural substance that has many applications. It is extensively used in the food, cosmetic, and pharmaceutical industries. It is also used as an additive and emulsifier. In some societies, GA is commonly used as a treatment for some chronic diseases such as diabetes mellitus [12]. GA is a combination of inorganic salts and polysaccharides. The inorganic salts are usually composed of $\mathrm{K}, \mathrm{Ca}$, and $\mathrm{Mg}$. The polysaccharide portion is composed of repeated units $\beta$-d-galactopyranosyl and glucuronic acid [13].

The use of gum Arabic-magnetite has been reported for the removal of $\mathrm{Cu}(\mathrm{II})$ ions from aqueous solutions. The maximum adsorption capacity was determined as $38.5 \mathrm{mg} / \mathrm{g}$ and the adsorption process was found to be endothermic [14]. It is also reported that GA/MNPs have been used to adsorb methylene blue dye from synthetic wastewater. Results showed that the maximum adsorption capacity was $8.8 \mathrm{mg} / \mathrm{g}$ and the adsorption process followed the Langmuir isotherm model [15]. Removal of $\mathrm{Pb}$ (II) ions from water was reported using several types of nanocomposites such as a polymer-based graphene oxide nanocomposite [16], nanocomposite of $\mathrm{ZnO}$ with montmorillonite [17], and cellulose acetate/titanium oxide nanocomposite [18].

In this study, a gum Arabic-magnetite composite (GA/MNPs) was synthesized, characterized, and assessed by several spectroscopic and analytical methods as an adsorbent for $\mathrm{Pb}$ (II) ions from synthetic wastewater. The GA/MNP composite is a partially bio-based material and has unique properties. Furthermore, GA is a low cost and available material. It is reported that the mixing of the magnetite nanoparticles with GA improves particle stability in aqueous suspensions and resulted in the formation of smaller agglomerates compared to the untreated samples [19]. These properties make it appropriate for many applications such as the removal of pollutants from water. The composite was prepared by the solution method and characterized using several techniques such as Fourier transform infrared spectroscopy (FTIR), X-ray diffraction (XRD), scanning electron microscopy (SEM), transmission electron microscopy (TEM), and thermogravimetric analysis (TGA).

\section{Materials and Methods}

\subsection{Materials}

$\mathrm{FeCl}_{2} \cdot 4 \mathrm{H}_{2} \mathrm{O}(>99 \%)$ and $\mathrm{FeCl}_{3} \cdot 6 \mathrm{H}_{2} \mathrm{O}(>99 \%)$ used for MNP preparation were obtained from Sigma-Aldrich (Saint Louis, MO, USA), $\mathrm{NH}_{3} \cdot \mathrm{H}_{2} \mathrm{O}\left(\mathrm{NH}_{3}\right.$ content, 28-30\%) and GA was purchased from Sigma-Aldrich.

\subsection{Preparation of $G A / M N P S$}

First, MNPs were prepared via co-precipitation as previously reported [20]. Briefly, $3.0 \mathrm{~g}$ GA was suspended in $100 \mathrm{~mL}$ of distilled water, then treated with $100 \mathrm{~mL}$ ferricferrous solution containing 0.01 $\mathrm{M}$ ferrous chloride tetrahydrate and $0.02 \mathrm{M}$ of anhydrous ferric chloride (stoichiometric ratio of 1:2). The reaction mixture was titrated very slowly (150 rpm) with ammonium hydroxide solution (9 M) until its $\mathrm{pH}$ reached 12 . The dark composite $\left(\mathrm{GA} / \mathrm{Fe}_{3} \mathrm{O}_{4}\right)$ was washed using distilled water until the $\mathrm{pH}$ of the washing solution was neutral. The produced composite was collected by a magnet and air dried at $70{ }^{\circ} \mathrm{C}$ for $12 \mathrm{~h}$.

\subsection{Characterization of the Prepared Composite}

Fourier transform infrared spectra of GA, GA/MNPs, and GA/MNPs-Pb(II) were analyzed using a NICOLET 6700 Thermo Scientific spectrometer (Thermo Fisher Scientific, Waltham, MA, USA). The materials' morphologies were analyzed via scanning electron microscopy (SEM-FEI; Quanta 200, Thermo Fisher Scientific, Waltham, MA, USA) and transmittance electron microscopy (TEM) using JEM-2100 (JEOL, Boston, MA, USA) at $200 \mathrm{kV}$. The magnetic behavior of the sample was studied using a SQUID-Vibrating sample 
magnetometer (SVSM, Quantum design. Akron, OH, USA). The material's thermal stability was analyzed using the TGA-50H thermal analyzer (Shimadzu, Kyoto, Japan) with a temperature range of $25-600{ }^{\circ} \mathrm{C}$ with a heating rate of $10^{\circ} \mathrm{C} / \mathrm{min}$ under a nitrogen atmosphere.

\subsection{Adsorption Experiments}

Due to the easiness of the process and the complete control of all factors, adsorption experiments were performed using the batch technique. All variables affecting the adsorption efficiency such as $\mathrm{pH}$ of the media (1.00-11.00), adsorbent mass $(0.3 \mathrm{~g} / 50 \mathrm{~mL})$, contact time (5-60 min), initial $\mathrm{Pb}(\mathrm{II})$ concentration (50-300 mg/L), and temperature (298-328 K) were studied by changing one variable when all other factors $(\mathrm{pH}$, adsorbent mass, contact time, and initial $\mathrm{Pb}$ (II) concentration) were kept constant. Each experiment was repeated three times to ensure the reproducibility of the results. Data showing standard deviation greater than $5 \%$ were rejected.

The removal percentage $(\mathrm{R} \%)$ of $\mathrm{Pb}$ (II) ions from aqueous solutions can be calculated using Equation (1):

$$
\mathrm{R} \%=\frac{\mathrm{C}_{\mathrm{o}}-\mathrm{C}_{\mathrm{e}}}{\mathrm{C}_{\mathrm{o}}} \times 100
$$

where $C_{o}$ and $C_{e}$ are the initial and equilibrium concentration of $\mathrm{Pb}(\mathrm{II})$ ions.

\subsection{Kinetic Studies}

The kinetic behavior of the adsorption process was investigated using various kinetic models. Equation (2) gives the Lagergren pseudo-first-order model [7].

$$
\ln \left(\mathrm{q}_{\mathrm{e}}-\mathrm{q}_{\mathrm{t}}\right)=\ln \mathrm{q}_{\mathrm{e}}-\mathrm{k}_{1} \mathrm{t}
$$

The pseudo-second-order equation is presented in Equation (3):

$$
\frac{\mathrm{t}}{\mathrm{q}_{\mathrm{e}}}=\frac{1}{\mathrm{k}_{2} \mathrm{q}_{\mathrm{e}}^{2}}+\frac{\mathrm{t}}{\mathrm{q}_{\mathrm{e}}}
$$

where $\mathrm{q}_{\mathrm{e}}$ and $\mathrm{q}_{\mathrm{t}}(\mathrm{mg} / \mathrm{g})$ are the adsorbed amounts of $\mathrm{Pb}(\mathrm{II})$ ions by $0.30 \mathrm{~g}$ of the composite at equilibrium and time $t$, respectively. $\mathrm{k}_{1}\left(\mathrm{~min}^{-1}\right)$ is the pseudo-first-order constant for the adsorption, $\mathrm{k}_{2}\left(\mathrm{~g} \mathrm{mg}^{-1} \mathrm{~min}^{-1}\right)$ is the pseudo-second-order constant.

The intra-particle diffusion kinetic model is displayed by Equation (4)

$$
\mathrm{q}_{\mathrm{t}}=\mathrm{k}_{\mathrm{id}} \mathrm{t}^{1 / 2}+\mathrm{I}
$$

where $\mathrm{I}$ is a boundary layer thickness constant $(\mathrm{mg} / \mathrm{g})$ and $\mathrm{k}_{\mathrm{id}}$ is the diffusion rate constant (mg/g. min).

Elovich model was also used to explore the kinetics of the adsorption process. The linear equation of this model is given in Equation (5):

$$
\mathrm{q}_{\mathrm{t}}=\left(\frac{1}{\beta}\right) \ln (\alpha \beta)+\left(\frac{1}{\beta}\right) \ln \mathrm{t}
$$

where $\alpha$ and $\beta$ are Elovich constants; $\mathrm{q}_{\mathrm{t}}(\mathrm{mg} / \mathrm{g})$ is the adsorbed quantity of $\mathrm{Pb}(\mathrm{II})$ ions onto GA/MNPs; and $\mathrm{t}(\mathrm{min})$ is the time.

\subsection{Adsorption Isotherms Models}

Among the various isotherm models, four were adopted in this work: Langmuir, Freundlich, Temkin, and Dubinin-Radushkevich.

Equation (6) illustrates the Langmuir isotherm model.

$$
\frac{\mathrm{C}_{\mathrm{e}}}{\mathrm{q}_{\mathrm{e}}}=\frac{\mathrm{C}_{\mathrm{e}}}{\mathrm{q}_{\max }}+\frac{1}{\mathrm{~b} \mathrm{q_{ \operatorname {max } }}}
$$


where $\mathrm{q}_{\mathrm{e}}$ is the quantity of $\mathrm{Pb}(\mathrm{II})$ ions removed $(\mathrm{mg} / \mathrm{g}) ; \mathrm{C}_{\mathrm{e}}$ is the remaining $\mathrm{Pb}$ (II) ion concentration $(\mathrm{mg} / \mathrm{L}) ; \mathrm{q}_{\max }$ is the maximum adsorption capacity of the composite $(\mathrm{mg} / \mathrm{g})$; and $b$ is the Langmuir constant $(\mathrm{L} / \mathrm{mg})$.

$$
\mathrm{R}_{\mathrm{L}}=\frac{1}{1+\mathrm{bC}_{\mathrm{o}}}
$$

where $\mathrm{C}_{\mathrm{o}}$ is the maximum initial concentration of $\mathrm{Pb}(\mathrm{II})$ ions.

The linear Freundlich model is presented by Equation (8)

$$
\ln \mathrm{q}_{\mathrm{e}}=\ln \mathrm{k}_{\mathrm{f}}+\mathrm{n} \ln \mathrm{C}_{\mathrm{e}}
$$

where $\mathrm{k}_{\mathrm{f}}(\mathrm{mg} / \mathrm{g}) /(\mathrm{mg} / \mathrm{L})$ and $\mathrm{n}$ (dimensionless) are the Freundlich constants.

The Temkin model was also investigated and is given by Equation (9):

$$
\mathrm{q}_{\mathrm{e}}=\mathrm{B} \ln \mathrm{A}+\mathrm{B} \ln \mathrm{C}_{\mathrm{e}}
$$

where $T$ is the temperature in Kelvin; $B=(R T) / b_{t}$ and $R$ is the gas constant; and $b_{t}$ is a constant associated with the adsorption heat $(\mathrm{J} / \mathrm{mol})$. A is the equilibrium binding constant corresponding to the maximal energy of binding.

The Dubinin-Radushkevich (DR) model was exploited in this study. The DR equation is displayed in Equation (10):

$$
\ln \mathrm{q}_{\mathrm{e}}=\ln \mathrm{q}_{\mathrm{m}}-\beta \varepsilon^{2}
$$

where $\varepsilon$ is represented by Equation (11)

$$
\varepsilon=\mathrm{RT} \ln \left(1+\frac{1}{\mathrm{C}_{\mathrm{e}}}\right)
$$

where $\beta$ is a constant related to the adsorption free energy, and $\mathrm{q}_{\mathrm{m}}(\mathrm{mg} / \mathrm{g})$ is the theoretical saturation capacity obtained from the DR model.

\subsection{Reusability of the Composite}

Desorption and reactivation of the adsorbent is a crucial concern, especially from the cost-effective point of view. In this study, GA/MNPs were reactivated by rinsing the used composite with deionized water and then treated with $0.01 \mathrm{M}$ sulfuric acid under continuous shaking for $2 \mathrm{~h}$. Then, the composite was filtered and washed with deionized water and reused for $\mathrm{Pb}$ (II) ion removal. Experiments were performed at the optimum conditions $(0.30 \mathrm{~g}$ of GA/MNPs per $50 \mathrm{~mL}$ of $50 \mathrm{mg} / \mathrm{L}$ of $\mathrm{Pb}(\mathrm{II})$ solutions, $\mathrm{pH}=6.00$, contact time $=30 \mathrm{~min}$, and $\mathrm{T}=298 \mathrm{~K})$.

\section{Results}

\subsection{Characterization}

\subsubsection{FTIR Spectroscopy}

The FTIR spectra of GA, GA/MNPs, and GA/MNPs-Pb(II) are given in Figure 1. The spectrum of GA showed the peaks at 3412, 2931, and $1608 \mathrm{~cm}^{-1}$ assigned for the $-\mathrm{OH}$ stretching, $-\mathrm{CH}_{2}$ stretching vibration [21], and $\mathrm{C}-\mathrm{O}$ asymmetric stretching vibrations, respectively. The peak at $1420 \mathrm{~cm}^{-1}$ is assigned to the wagging vibrations for $\mathrm{CH}$ and $-\mathrm{CH}$ [22]. The C-O-C linkage appeared at $1073 \mathrm{~cm}^{-1}$ [23], where the peak at $603 \mathrm{~cm}^{-1}$ could be assigned for the $\mathrm{C}-\mathrm{H}$ out-of-plane bending vibration [21]. The spectrum of GA/MNPs showed increased intensity for the peak at $1607 \mathrm{~cm}^{-1}$ with a very slight shift, indicating the formation of hydrogen bonding between the GA and the MNPs [24]. The GA/MNP-Pb spectrum showed a slight change in the intensities and positions of the major bands as the $\mathrm{C}=\mathrm{O}$ band at $1600 \mathrm{~cm}^{-1}$ and the $\mathrm{C}-\mathrm{O}$ bond appeared at 1068 and $1420 \mathrm{~cm}^{-1}$, reflecting the effect of $\mathrm{Pb}$ adsorption. 


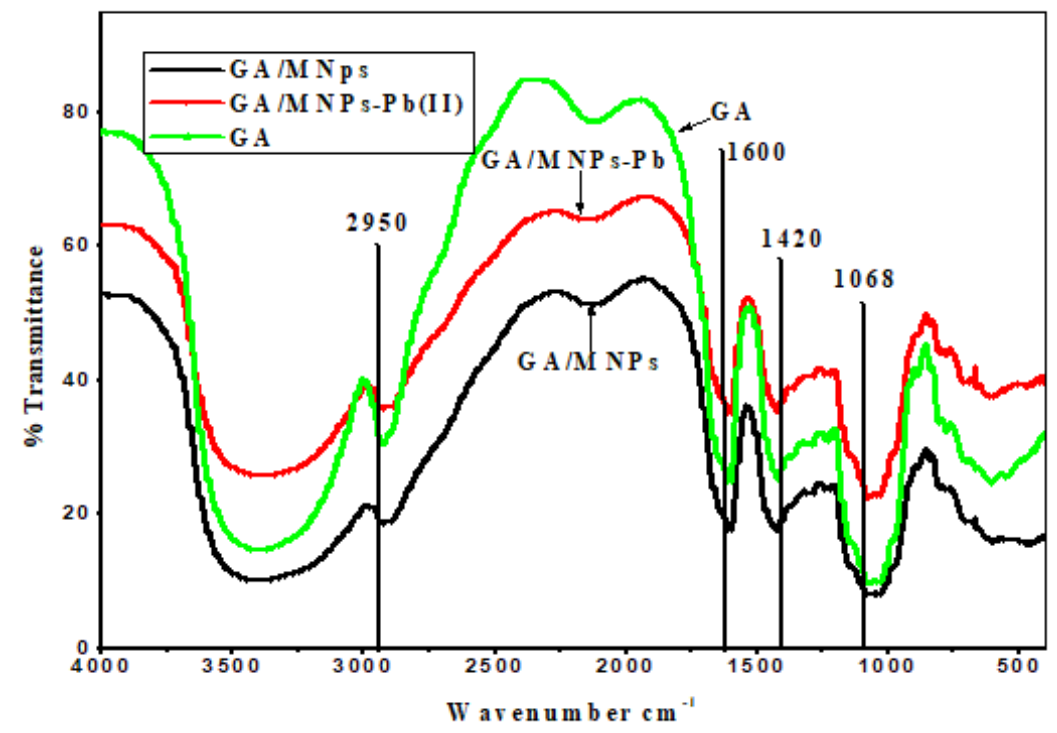

Figure 1. FTIR spectra of GA, GA/MNPs, and GA/MNPs-Pb(II).

\subsubsection{SEM}

The morphologies of the materials are presented in the SEM micrographs in Figure 2. The micrographs show the homogenous dispersion of MNPs within the composite with a small particle size compared to the GA particles. The results also showed evident variation in the particle surface morphology with clear surface pore and homogeneous MNP distribution within the GA/MNPs, which could provide synergistic adsorption for metal ions.

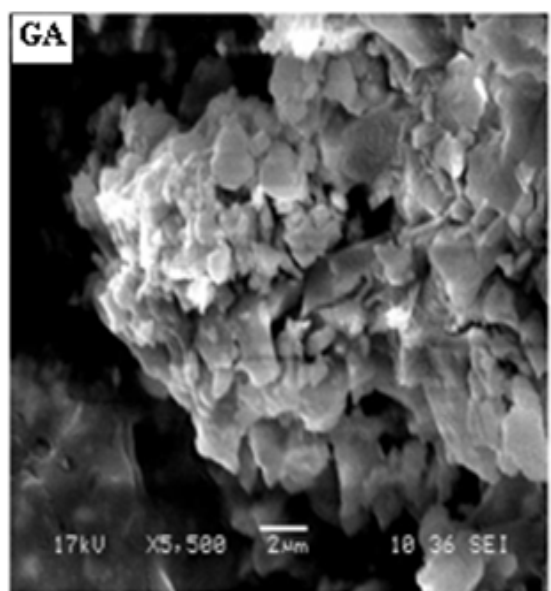

(a)

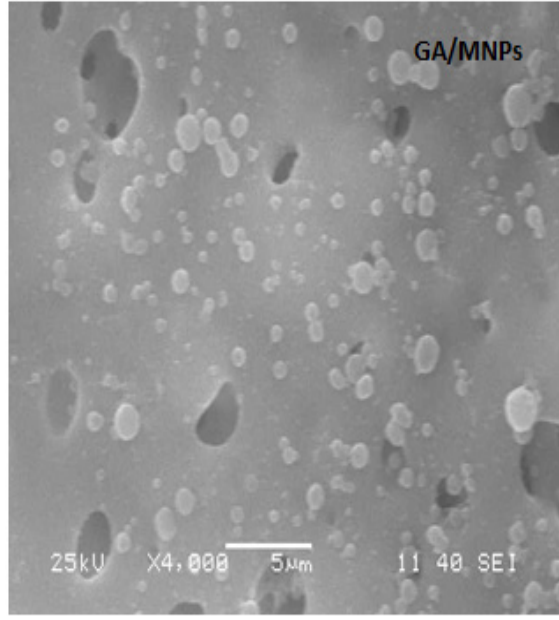

(b)

Figure 2. Morphology of (a) GA alone and (b) GA/MNPs.

\subsubsection{TEM}

The TEM images (Figure 3) confirm that the prepared GA/MNPs is a nanocomposite material and has a core shell structure as the MNPs appeared coated by GA. The preparation procedure may not achieve any particle accumulation. It was reported that magnetic nanoparticles with small particle sizes and reduced accumulation may have essential magnetic properties for many applications $[25,26]$. The TEM images also revealed welldispersed magnetite nanoparticle MNPs within the GA with uniform size and shape. The content of magnetite particles and the formation of the core shell structure may indicate high magnetization properties of the GA/MNPs composite. 


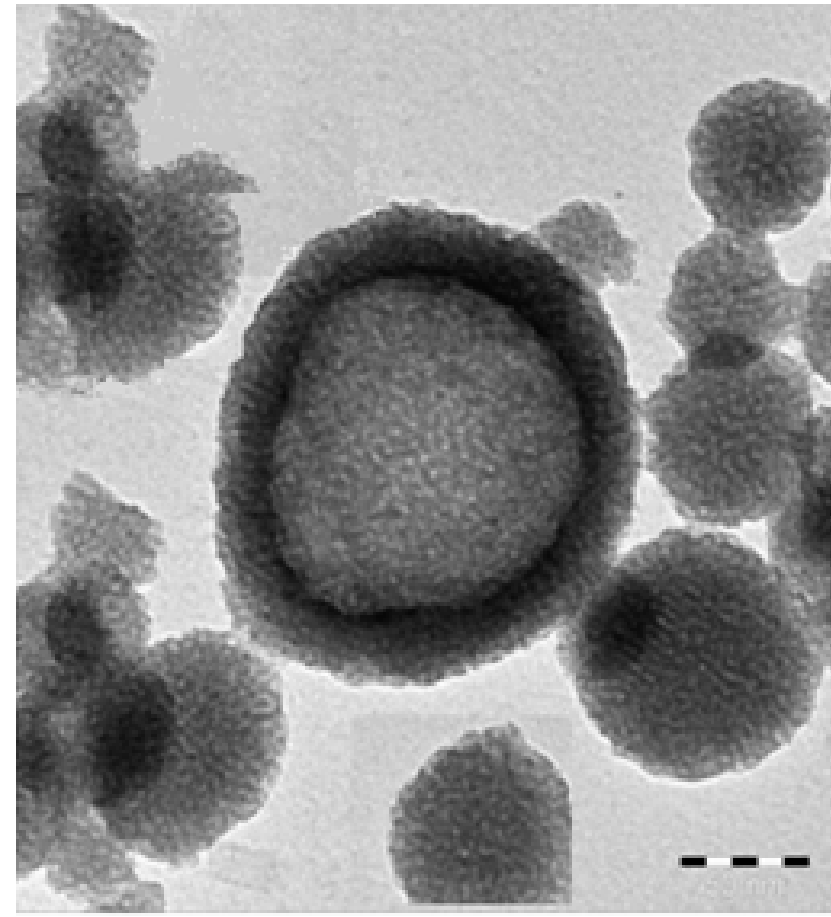

(a)

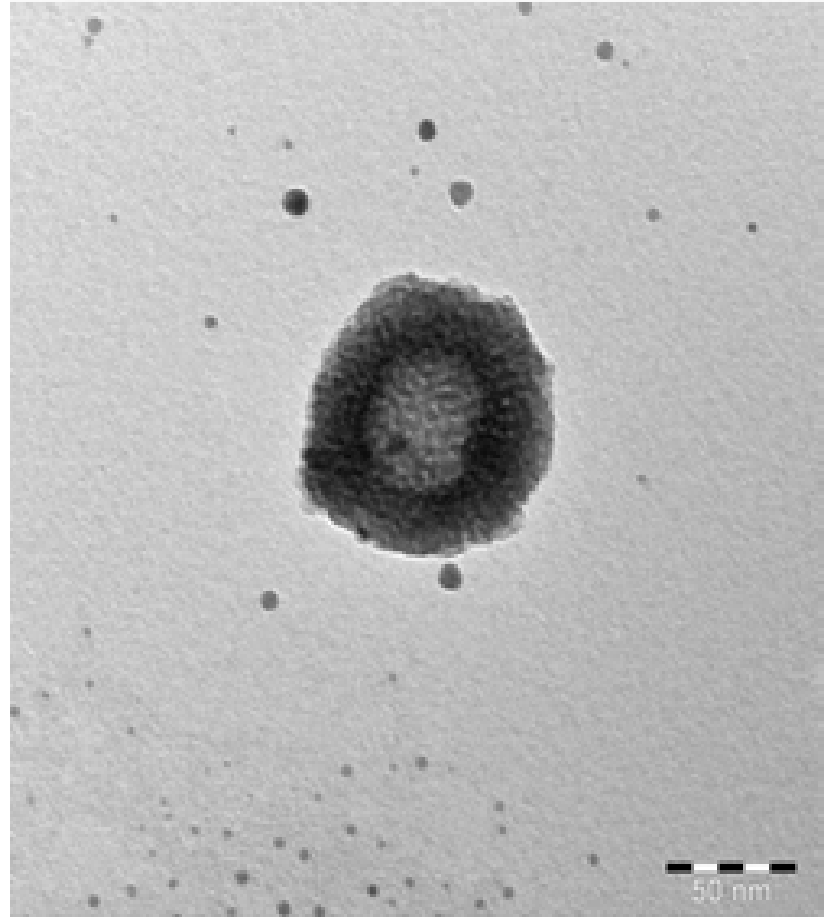

(b)

Figure 3. TEM images for the (a) GA/MNP and (b) MNP distribution.

\subsubsection{XRD}

$X$-ray diffraction pattern provides structural information including the amorphous and crystalline structure of the material. The XRD pattern of the pure GA showed only one diffused peak near $2 \theta=20.3^{\circ}$ due to its poor crystallinity [22,23]. The XRD image of GA/MNPs is shown in Figure 4. GA/MNPs showed five sharp peaks at $2 \theta=30.1^{\circ}, 35.8^{\circ}$, $43.0^{\circ}, 57.5^{\circ}$, and $63.2^{\circ}$ due to the good crystallinity of GA/MNPs, proving the incorporation of the MNPs into the GA backbone. Moreover, the well crystallized peak at $35.8^{\circ}$ proves the existence of $\mathrm{Fe}_{3} \mathrm{O}_{4}[25,26]$.

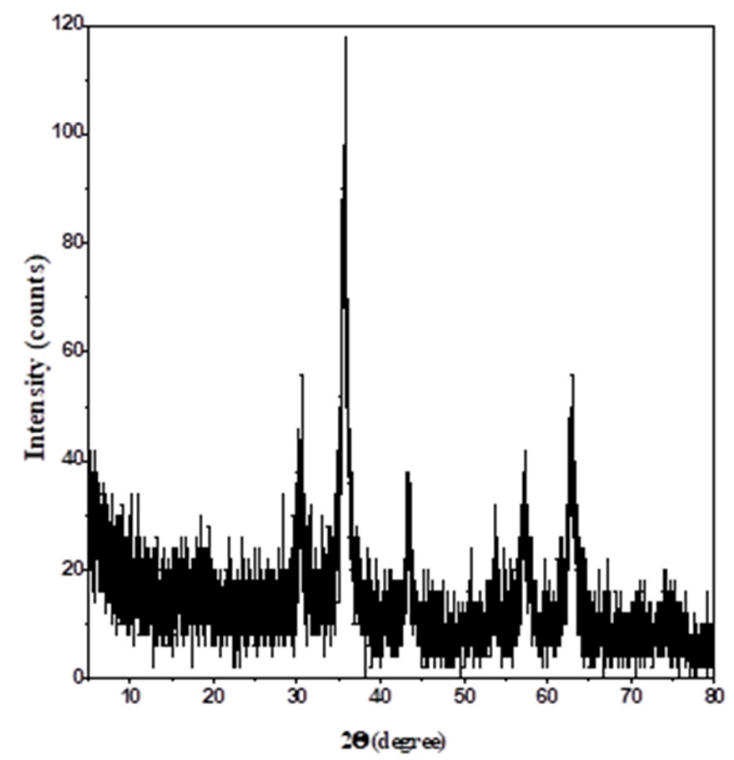

Figure 4. XRD pattern for GA/MNPs. 


\subsubsection{TGA}

The TGA weight loss percentage is given in Figure 5 for GA and GA/MNPs. The results showed that the inclusion of MNPs within the composite GA/MNPs improved the thermal stability of the produced composite. The weight loss percentage reached about $80 \%$ for GA. The first weight loss appeared between 100 to $300{ }^{\circ} \mathrm{C}$ for GA, which involved the removal of absorbed water molecules by gradual dehydration. The second weight loss appeared between $300^{\circ} \mathrm{C}$ and $450{ }^{\circ} \mathrm{C}$, which could be assigned for the decomposition of hydrocarbons. The TGA of the GA/MNPs showed lower weight loss with delayed thermal degradation. This finding could be due to the formation of an expanded layer on the GA surface and the MNPs, which highly affect the thermal stability of the GA/MNP composite. The MNPs could act as a barrier layer, protect GA from thermal degradation, and decrease the heat transfer within the composite [27].

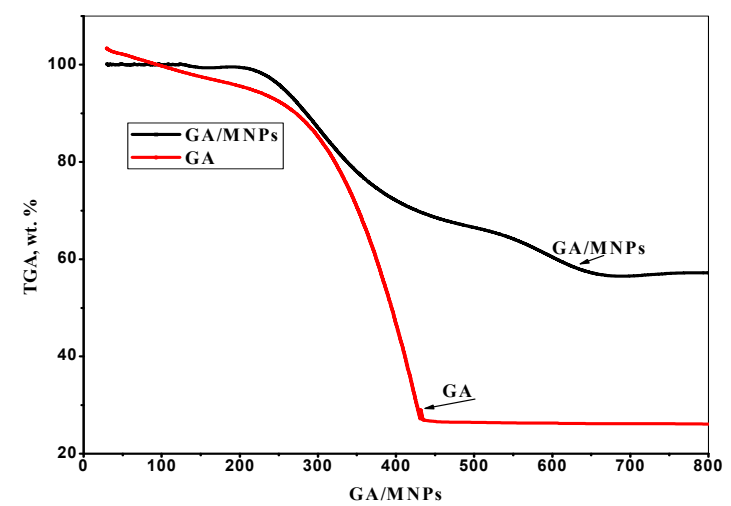

Figure 5. TGA analyses for GA and GA/MNPs.

\subsubsection{Magnetic Properties}

The magnetic properties of the GA/MNP composite were investigated using the vibrating sample magnetometer (VSM) technique. The observed magnetic properties of the prepared particles reflected their dispersion/aggregation and morphological properties. Figure 6 indicates that the magnetic properties reflect the inclusion of MNP within the composite adsorbent as polydisperse particles or monodisperse. The observed magnetic properties confirm the formation of particles with consistent MNP distribution within the composite. The adsorbent particles showed superparamagnetic behavior at ambient temperature.

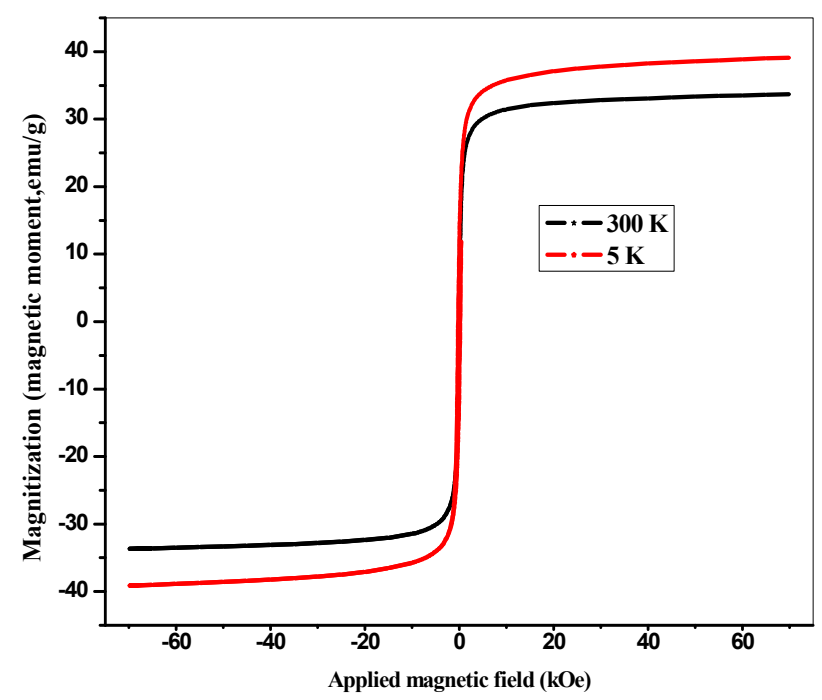

Figure 6. VSM analysis of the GA/MNPs. 


\subsection{Adsorption Studies}

\subsubsection{GA Capacity to Adsorb $\mathrm{Pb}$ (II) Ions}

Several experiments were conducted to examine the ability of GA alone to remove the $\mathrm{Pb}$ (II) ions from aqueous solutions. Results showed that the efficiency of GA in all experiments did not exceed $5 \%$.

\subsubsection{Influence of $\mathrm{pH}$}

All adsorption systems are likely to be affected by the $\mathrm{pH}$ value of the media, which can control the binding of the adsorbate onto the adsorbent surface. In this work, the $\mathrm{GA} / \mathrm{MNP}$ composite was tested for the removal of $\mathrm{Pb}$ (II) ions from aqueous solutions in the $\mathrm{pH}$ range of 1.00 to 11.00. The adsorption profile is presented in Figure 7. As expected, in all studied ranges, the effect of the $\mathrm{pH}$ value was profound. The maximum adsorption capacity increased with $\mathrm{pH}$ increase, reaching a maximum and then decreasing with $\mathrm{pH}$ increase. The low adsorption efficiency at low $\mathrm{pH}$ values is most likely due to the competition between $\mathrm{H}^{+}$ions and $\mathrm{Pb}^{2+}$ ions on adsorption sites. As the $\mathrm{pH}$ value increases, more carboxylate groups $(-\mathrm{COOH})$ from the composite surface could be dissociated into a negatively charged group (-COO-), leading to high adsorption capacity. The adsorption efficiencies decreased sharply above $\mathrm{pH} 6.00$ because lead hydroxides precipitate above this $\mathrm{pH}$ value $[28,29]$.

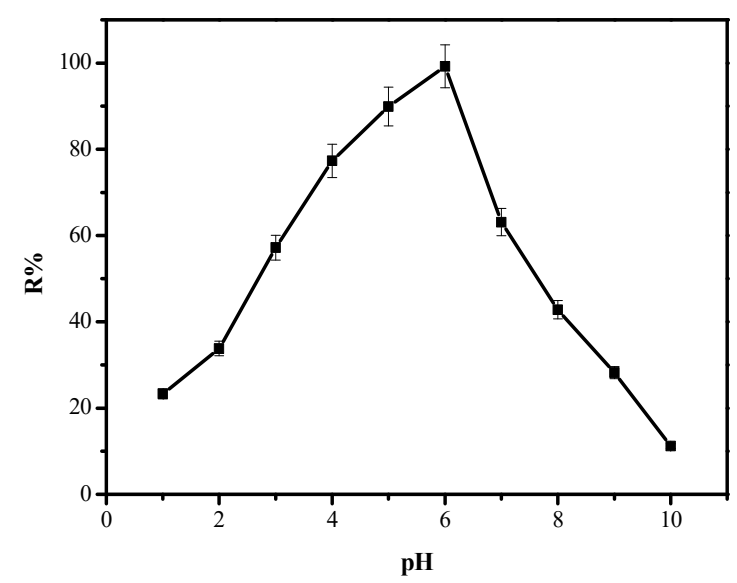

Figure 7. Effect of $\mathrm{pH}$ on the efficiency of the GA/MNP composite for the removal $\mathrm{Pb}(\mathrm{II})$ from an aqueous solution at $298 \mathrm{~K}$.

\subsubsection{Effect of Contact Time}

In all adsorption experiments, contact time is a significant factor as it strongly influences the adsorbent efficiency. Figure 8 shows the results from the experiments performed under different contact time while keeping all of the other factors constant $(\mathrm{pH}=6.00$, adsorbent mass $=0.30 \mathrm{~g}, \mathrm{~Pb}(\mathrm{II})$ ion concentration $=50 \mathrm{mg} / \mathrm{L}$, and temperature $=298 \mathrm{~K})$. It was found that the composite reached the maximum removal efficiency $(98.8 \%)$ in $30 \mathrm{~min}$. A contact time of $30 \mathrm{~min}$ was chosen for all other experiments. 


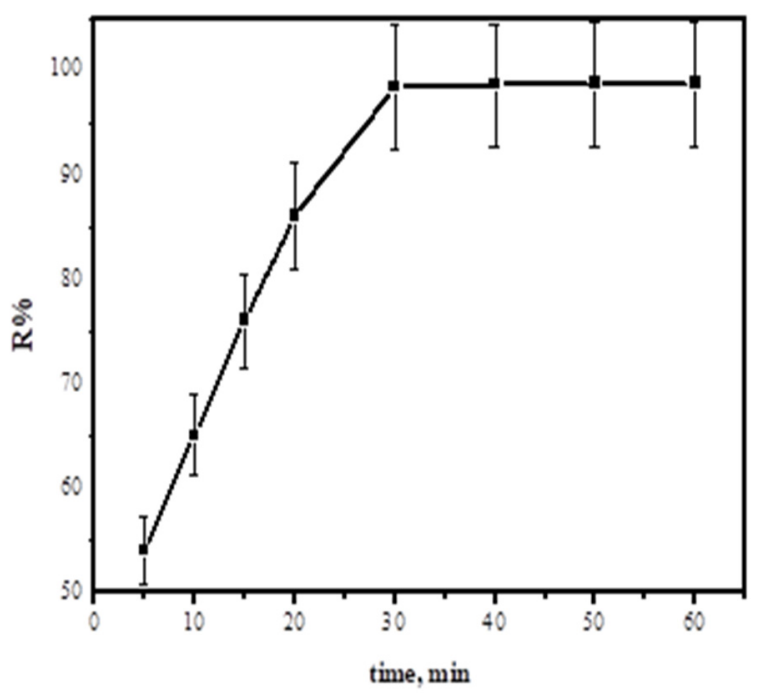

Figure 8. Effect of the contact time of removal efficiency of $\mathrm{Pb}(\mathrm{II})$ ions by the GA/MNP composite at $298 \mathrm{~K}$.

\subsubsection{Kinetic Behavior}

The kinetics and mechanism of the $\mathrm{Pb}(\mathrm{II})$ ion uptake were assessed by testing the experimental data using various kinetic models.

Pseudo-First and Second-Order Models

The linear plots for both models were exploited to assess the applicability of both models. The kinetic parameters are displayed in Table 1. Based on the obtained correlation coefficient $\left(\mathrm{R}^{2}\right)$, the experimental data showed well-fitting with the pseudo-second-order model (Figure $9 \mathrm{~b}$ ). The theoretical adsorption capacity obtained from the pseudo-secondorder model $(55.2 \mathrm{mg} / \mathrm{g})$ is in good agreement with that obtained from the Langmuir model $(50.5 \mathrm{mg} / \mathrm{g})$.

Table 1. Kinetic data of the adsorption of $\mathrm{Pb}(\mathrm{II})$ ions onto GA/MNPs.

\begin{tabular}{ccc}
\hline Kinetic Model & Parameters \\
\hline \multirow{3}{*}{ first order } & $\mathrm{q}_{\mathrm{e}}(\mathrm{mg} / \mathrm{g})$ & 25.1 \\
& $\mathrm{k}_{1}\left(\mathrm{~min}^{-1}\right)$ & 0.0792 \\
& $\mathrm{R}^{2}$ & 0.8595 \\
\hline \multirow{3}{*}{ second order } & $\mathrm{q}_{\mathrm{e}}(\mathrm{mg} / \mathrm{g})$ & 55.2 \\
& $\mathrm{k}_{2}(\mathrm{~g} / \mathrm{mg} \cdot \mathrm{min})$ & 0.0181 \\
& $\mathrm{R}^{2}$ & 0.9937 \\
\hline \multirow{3}{*}{ Intra-particle diffusion } & $\mathrm{k}_{\mathrm{id}}(\mathrm{mg} / \mathrm{g} \cdot \mathrm{min})$ & 4.45 \\
& $\mathrm{I}$ & 23.5 \\
& $\mathrm{R}^{2}$ & 0.9043 \\
\hline & $\mathrm{A}$ & $30 \times 10^{68}$ \\
Elovich & $\mathrm{B}$ & 0.121 \\
& $\mathrm{R}^{2}$ & 0.9378 \\
\hline
\end{tabular}



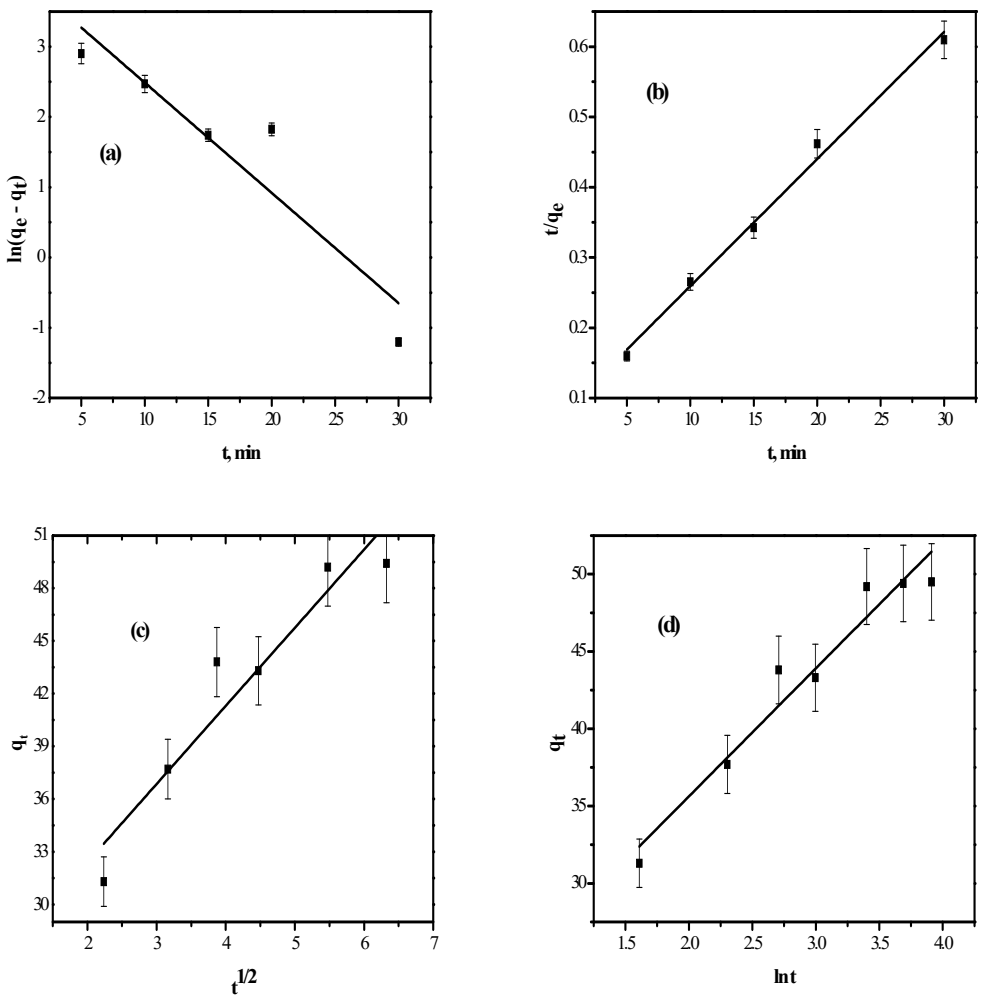

Figure 9. Kinetic models for adsorption system of removal of $\mathrm{Pb}$ (II) ion using GA/MNPs: (a) pseudo-first-order; (b) pseudo-second-order; (c) intra-particle diffusion; (d) Elovich.

\section{Intra-Particle Diffusion Kinetic Model}

Equation (4) was applied to study the kinetic behavior of the adsorption process using the intra-particle diffusion model. The $\mathrm{k}_{\mathrm{id}}$ value was calculated from the slope of Equation (4) and Figure 9c and is displayed in Table 1. The plot of qt against $\mathrm{t}^{1 / 2}$ was curved, showing that numerous processes control the adsorption system. The non-linear portion of the plot is attributable to the effect of boundary layer diffusion and means that the rate constant $\left(\mathrm{k}_{\mathrm{id}}\right)$ is controlling the intra-particle diffusion [7].

\section{Elovich Model}

The modified form of the Elovich model [30] was also used to investigate the kinetic behavior of adsorption of $\mathrm{Pb}$ (II) ions onto GA/MNPs. The Elovich equation [30,31] was frequently exploited to examine the kinetic behavior of the chemical adsorption of gases on solid surfaces. Currently, it was stated [30] that this model can also be used to study the adsorption from aqueous solutions. The importance of $\alpha$ and $\beta$ constants has not been undoubtedly determined [32]. The plot of $q_{t}$ against $\ln t$ is shown in Figure $9 d$, and the values of $\alpha$ and $\beta$ constants as well as the correlation coefficient $\left(R^{2}\right)$ are given in Table 1 . Results in Table 1 and Figure 9d confirmed that Elovich model did not fit linearly with the experimental data $\left(R^{2}=0.9043\right)$, indicating that this adsorption system cannot be defined by the Elovich model.

\subsubsection{Effect of Initial $\mathrm{Pb}$ (II) Concentration}

Figure 10 illustrates the effect of $\mathrm{Pb}$ (II) ion initial concentration on the removal percentage. The efficacy decreased from $98.8 \%$ to $62.7 \%$ as the initial $\mathrm{Pb}(\mathrm{II})$ ion concentration increased from 50 to $300 \mathrm{mg} / \mathrm{L}$. The decrease in adsorption efficiency can be ascribed to a lack of enough adsorbent surface area to gather the obtainable $\mathrm{Pb}$ (II) ions from the solution [26]. However, the uptake capacity improved from 12.4 to $47.2 \mathrm{mg} / \mathrm{g}$ as the preliminary $\mathrm{Pb}(\mathrm{II})$ ion concentration increased from 50 to $300 \mathrm{mg} / \mathrm{L}$. 


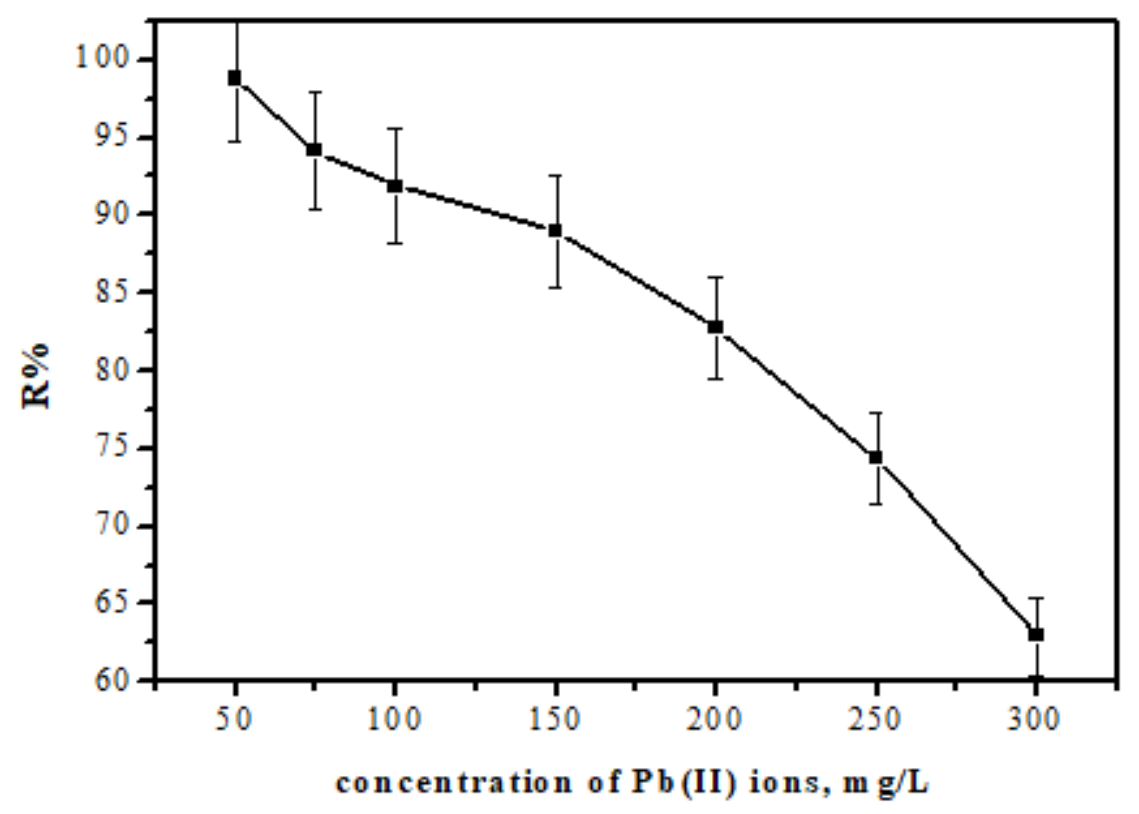

Figure 10. Effect of $\mathrm{Pb}$ (II) concentration on the efficiency of the GA/MNP composite for the removal of $\mathrm{Pb}$ (II) ions from synthetic wastewater at $298 \mathrm{~K}$.

\subsection{Isotherm Models}

The way by which the interface of $\mathrm{Pb}$ (II) ions and the adsorption sites of the composite occurs can be understood by adsorption isotherm models [33]. The adsorption isotherms are characterized by certain factors, whose values express the surface properties and affinity of the adsorbent for $\mathrm{Pb}(\mathrm{II})$ ion adsorption [34]. In the current study, these models were verified and several isotherms are displayed in Figure 8.

\subsubsection{Langmuir Model}

Figure 11a illustrates the plot of the Langmuir model. It is clear that the plot exhibited a straight line with the slope expressing the reciprocal of the maximum adsorption capacity and the intercept expressing $1 / \mathrm{bq}_{\max }$. A high $\mathrm{b}$ value indicates a more binding affinity between the adsorbate and adsorbent. The parameters obtained from this model are listed in Table 2. It can be deduced from the results shown in Table 2 and Figure 11a that the adsorption system obeyed the Langmuir Model $\left(R^{2}=0.996\right)$. The obtained $q_{\max }$ value was $50.5 \mathrm{mg} / \mathrm{g}$, which was very close to the values found at the optimal $\mathrm{pH}$ value and from the second-order kinetic model. The obtained $b$ value (0.871) relative to the reported values $[7,26]$ indicated a high attraction between the GA/MNPs and $\mathrm{Pb}$ (II) ions.

Additionally, substantial indication linked to adsorption nature can be obtained from the values of separation factor $\left(R_{L}\right)$, which is a significant feature of the Langmuir model. $R_{L}$ value is usually used to realize the nature of adsorbent/adsorbate affinity. $R_{L}$ values are determined by Equation (7).

The $R_{L}$ values designated the adsorption type as follows: (i) unfavorable $\left(R_{L}>1\right)$; (ii) linear $\left(R_{L}=1\right)$; and (iii) favorable $\left(0<R_{L}<1\right)$ or irreversible $\left(R_{L}=0\right)$. In this study, as shown in Table 2, all $\mathrm{R}_{\mathrm{L}}$ values were between 0 and showed that the adsorption system was a favorable process. 

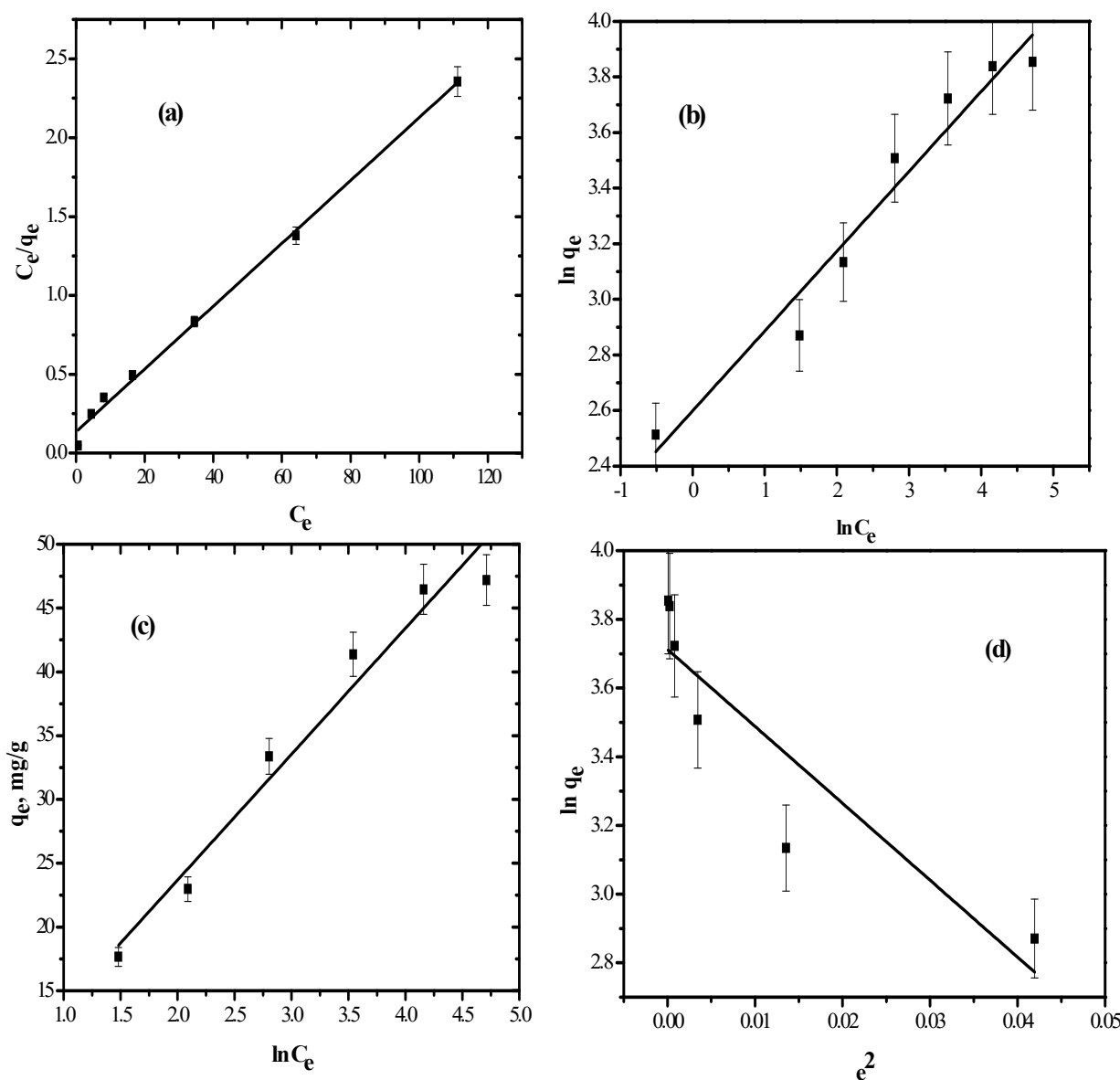

Figure 11. Adsorption isotherm: (a) Langmuir; (b) Freundlich; (c) Temkin; (d) DR models.

Table 2. Parameters of the adsorption isotherm models.

\begin{tabular}{ccc}
\hline Adsorption Model & Isotherm Parameters & Values \\
\hline \multirow{3}{*}{ Langmuir } & $\mathrm{q}_{\max }(\mathrm{mg} / \mathrm{g})$ & 50.5 \\
& $\mathrm{R}_{\mathrm{L}}(\mathrm{L} / \mathrm{g})$ & 0.029 \\
& $\mathrm{R}^{2}$ & 0.887 \\
\hline \multirow{3}{*}{ Freundlich } & $\mathrm{n}$ & 0.67 \\
& $\mathrm{~K}_{\mathrm{f}}(\mathrm{mg} / \mathrm{g}) /(\mathrm{mg} / \mathrm{L})$ & 4.6 \\
& $\mathrm{R}^{2}$ & 0.9981 \\
\hline \multirow{2}{*}{ Temkin } & $\mathrm{A}(\mathrm{L} / \mathrm{g})$ & 2.1 \\
& $\mathrm{~b}_{\mathrm{t}}(\mathrm{kJ} / \mathrm{mol})$ & 370.3 \\
& $\mathrm{R}^{2}$ & 0.899 \\
\hline \multirow{2}{*}{$\mathrm{DR}$} & $\beta$ & 22.4 \\
& $\mathrm{q}_{\mathrm{m}}(\mathrm{mg} / \mathrm{g})$ & 40.4 \\
& $\mathrm{E}_{\mathrm{f}}(\mathrm{kJ} / \mathrm{mol})$ & 0.15 \\
& $\mathrm{R}^{2}$ & 0.7864 \\
\hline
\end{tabular}

\subsubsection{Freundlich Model}

The values of the parameters extracted from Equation (8) and Figure $11 \mathrm{~b}$ are displayed in Table 2. It was found that the $\mathrm{n}$ value was greater than 1 , showing a favorable adsorption process [35]. This is in good agreement with the conclusions obtained from the $R_{L}$ values calculated from the Langmuir model. 


\subsubsection{Temkin Isotherm}

In the Temkin isotherm model, the heat of adsorption of all adsorbed particles in a single layer is expected to decrease sharply with the adsorbent surface coverage due to a reduction in the adsorbent/adsorbate interactions.

The values of the constants A and B are determined from the slope and intercept of Equation (9) and Figure 11c, as shown in Table 2. The $b_{t}$ value was found to be $251 \mathrm{~J} / \mathrm{mol}$, representing a physical adsorption system [36].

\subsubsection{Dubinin-Radushkevich Model}

The adsorption energy of the system can be deduced from the Dubinin-Radushkevich (DR) model. This model is usually exploited to obtain information about the adsorption mechanism [32]. The DR model is usually proposed only for both homogeneous and heterogonous adsorption systems.

Values of $q_{m}, \beta$, and $R^{2}$ were determined using Figure $11 d$ and displayed in Table 2 . The free energy of adsorption $E_{\mathrm{f}}$ is the free energy change when one mole of adsorbate is moved to the solid adsorbent surface and is determined using Equation (12):

$$
\mathrm{E}_{\mathrm{f}}=\frac{1}{\sqrt{2 \beta}}
$$

The type of the adsorption process can be obtained from the value of $E_{f}$. The adsorption system is considered chemical when the $E_{\mathrm{f}}$ value lies between 8.0 and $16.0 \mathrm{~kJ} / \mathrm{mol}$ and physical when $E_{\mathrm{f}}$ is smaller than $8.0 \mathrm{~kJ} / \mathrm{mol}$. The value of $E_{\mathrm{f}}$ displayed in Table 2 proves that the adsorption system is physical in nature. This conforms with the conclusions obtained from the Elovich kinetic model [7].

\subsection{Effect of Temperature}

The influence of temperature on the efficiency of the adsorption system was examined by conducting various experiments in the temperature range from 298 to $328 \mathrm{~K}$ while keeping the other optimal experimental circumstances constant $(\mathrm{pH}=6.00$, adsorbent mass $=0.3 \mathrm{~g}$, contact time $=30 \mathrm{~min}$, and $\mathrm{Pb}$ (II) ion concentration $=150 \mathrm{mg} / \mathrm{L}$ ). Results shown in Figure 12 show that the adsorption efficacy is directly proportional to temperature. This can be attributed to the activation of more adsorption sites on the adsorbent surface and the increase in the speed of $\mathrm{Pb}(\mathrm{II})$ ions at elevated temperatures.

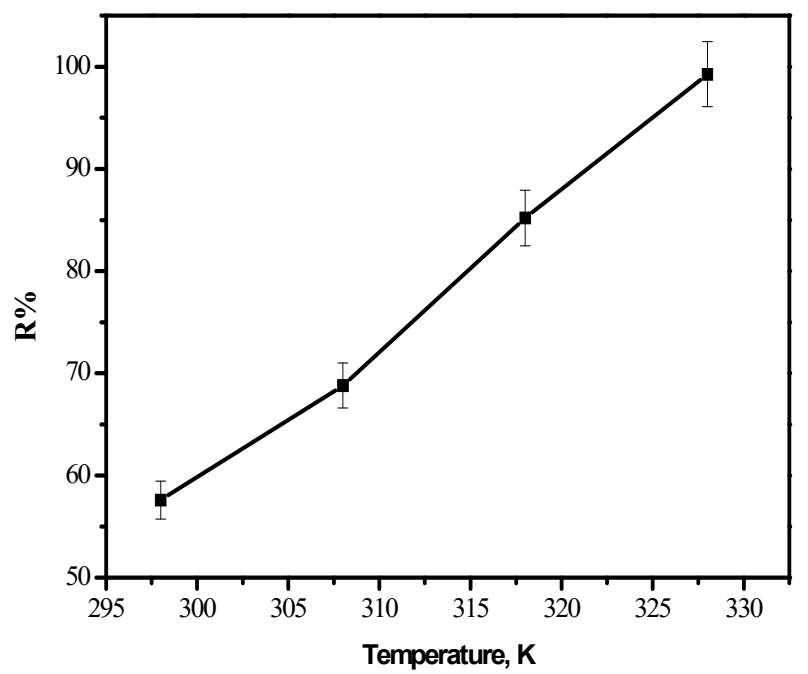

Figure 12. Effect of temperature on the efficacy of the removal of $\mathrm{Pb}(\mathrm{II})$ ions from synthetic wastewater by the GA/MNP composite. 


\subsection{Thermodynamic Parameters}

Some thermodynamic activation parameters, viz., entropy change of activation $\Delta \mathrm{S}$, enthalpy change of activation $\Delta \mathrm{H}$, and free energy change of activation $\Delta \mathrm{G}$, were determined using Equations (13)-(15):

$$
\begin{gathered}
\mathrm{K}_{\mathrm{D}}=\frac{\mathrm{C}_{\mathrm{o}}}{\mathrm{C}_{\mathrm{e}}} \\
\Delta \mathrm{G}^{\circ}=-\mathrm{RT} \ln \mathrm{K}_{\mathrm{c}} \\
\ln \mathrm{K}_{\mathrm{D}}=\frac{\Delta \mathrm{S}^{\circ}}{\mathrm{R}}-\frac{\Delta \mathrm{H}^{\circ}}{\mathrm{RT}}
\end{gathered}
$$

where $\mathrm{K}_{\mathrm{D}}$ is the distribution coefficient, $\mathrm{R}$ is the universal gas constant $\left(8.314 \mathrm{JK}^{-1} \mathrm{~mol}^{-1}\right)$ and $\mathrm{T}(\mathrm{K})$ is the temperature.

The plot of $\ln K_{D}$ against $1 / T$ as shown in Figure 13 was exploited to determine the values of both $\Delta \mathrm{H}^{\circ}$ and $\Delta \mathrm{S}^{\circ}$. The results are displayed in Table 3 . The obtained positive value of $\Delta \mathrm{H}^{\circ}$ proves the endothermic nature of the adsorption system, while the positive value of $\Delta \mathrm{S}^{\circ}$ suggests the spontaneous nature of the $\mathrm{Pb}$ (II) ion removal process. Furthermore, the high value of $\Delta \mathrm{S}^{\circ}$ indicates an irregular and permeable adsorbent. Moreover, in all experiments, $\Delta \mathrm{G}^{\circ}$ showed negative values that increased by rising temperature, suggesting a favorable adsorption process at elevated temperatures that conforms with the observation that the adsorption efficiency increases with temperature. It is reported that the adsorption process is considered physical when the adsorption free energy change $\left(\Delta \mathrm{G}^{\circ}\right)$ ranges between -20 and $0 \mathrm{~kJ} / \mathrm{mol}$ and chemical when $\Delta \mathrm{G}^{\circ}$ ranges between -400 and $-80 \mathrm{~kJ} / \mathrm{mol}$. Thus, the adsorption nature for the current process is physical $[7,37-39]$.

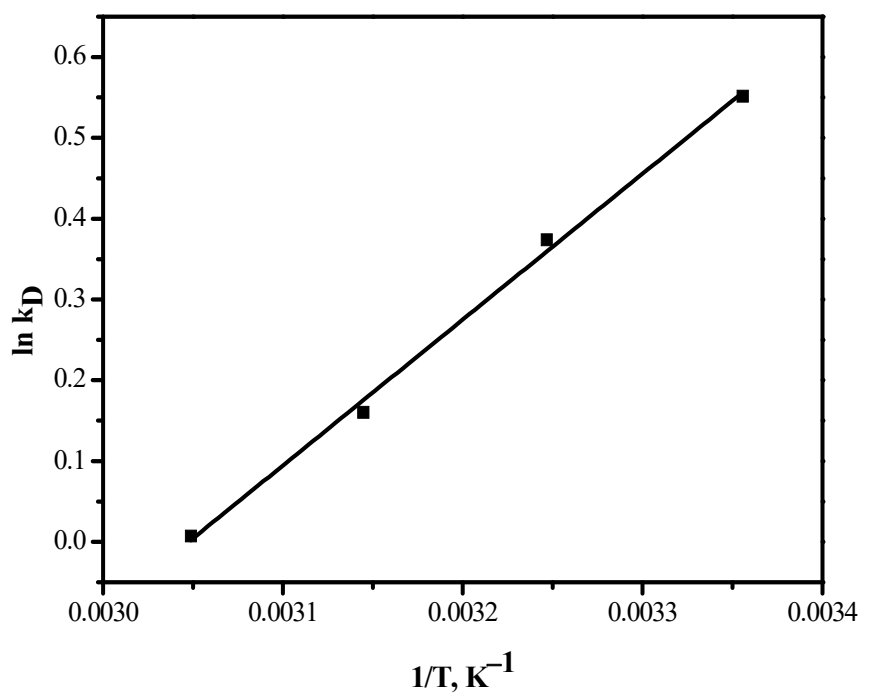

Figure 13. Plot of $\ln \mathrm{k}_{\mathrm{D}}$ against $1 / \mathrm{T}$.

Table 3. Thermodynamic parameters of the adsorption of $\mathrm{Pb}(\mathrm{II})$ ions on the GA/MNP surface.

\begin{tabular}{cccc}
\hline T, K & $\Delta \mathbf{G}, \mathbf{k J} / \mathbf{m o l}$ & $\Delta \mathbf{S}, \mathbf{J} / \mathbf{m o l ~ K}$ & $\Delta \mathbf{H}, \mathbf{k J} / \mathbf{m o l}$ \\
\hline 298 & -6.1 & & \\
308 & -6.5 & 26.6 & 15.0 \\
318 & -6.8 & & \\
328 & -7.3 & & \\
\hline
\end{tabular}

\subsection{Selectivity}

The selective adsorption investigations were performed using an aqueous solution containing a mixture of multi-interfering ions including $\mathrm{Cr}(\mathrm{III}), \mathrm{Cu}(\mathrm{II})$, and $\mathrm{Ni}(\mathrm{II})$. The competing metal ions were selected based on either similar mode coordination or charge, 
besides the co-occurrence of such solutions within the real effluent from various industrial sectors. Results displayed in Table 4 show that the efficiency of removal of $\mathrm{Pb}$ (II) by GA/MNPs slightly decreased with the increase in concentration of these interfering ions, indicating a moderate selectively trend of GA/MNPs toward $\mathrm{Pb}(\mathrm{II})$ ions.

Table 4. The removal efficiency of $\mathrm{Pb}(\mathrm{II})$ by GA/MNPs in the presence of some interfering ions.

\begin{tabular}{ccc}
\hline Existing Metal Ion & Concentration of Each Metal & $\mathbf{R} \%$ of Pb(II) Ions \\
\hline $\mathrm{Cr}(\mathrm{III}), \mathrm{Ni}(\mathrm{II}), \mathrm{Cu}(\mathrm{II})$ & $5.0 \mathrm{mg} / \mathrm{L}$ & 92 \\
$\mathrm{Cr}(\mathrm{III}), \mathrm{Ni}(\mathrm{II}), \mathrm{Cu}(\mathrm{II})$ & $10.0 \mathrm{mg} / \mathrm{L}$ & 88 \\
$\mathrm{Cr}(\mathrm{III}), \mathrm{Ni}(\mathrm{II}), \mathrm{Cu}(\mathrm{II})$ & $15 \mathrm{mg} / \mathrm{L}$ & 84 \\
\hline
\end{tabular}

\subsection{Reusability of the Composite}

The adsorption and reactivation processes were performed four times using the same composite. Figure 14 shows the removal efficiency in each case. The removal efficiency decreased gradually from 95.6 when the GA/MNPs were used for the first time until it reached, in the last cycle, $81 \%$ of its initial efficiency. These results confirm the high reusability performances of the composite at least three times.

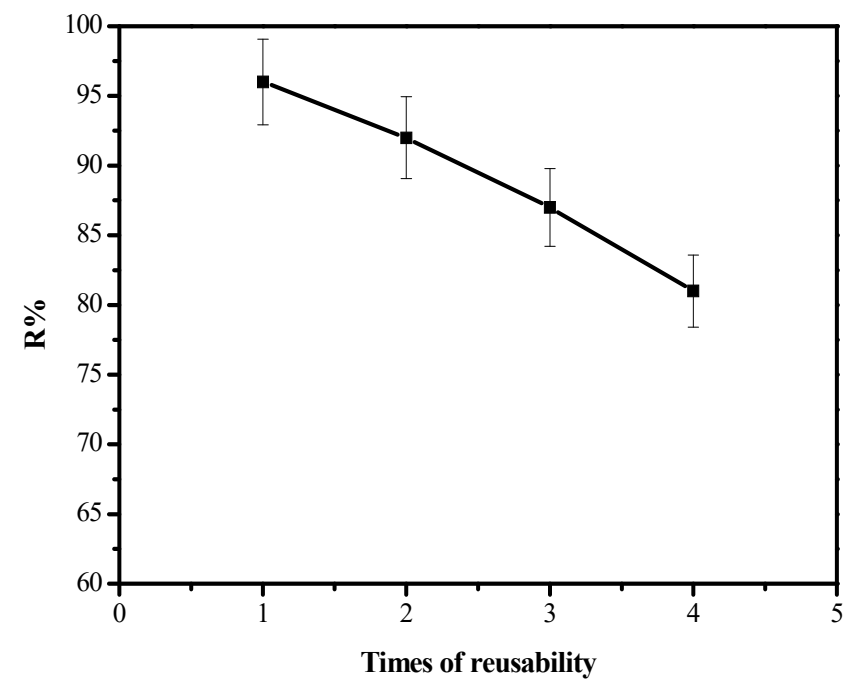

Figure 14. Reusability of the GA/MNPs for the removal of $\mathrm{Pb}(\mathrm{II})$ ions.

\subsection{Comparison of GAMNPs with Other Materials Used for Pb(II) Removal}

The maximum uptake capacity and some experimental optimum conditions for the adsorption process of $\mathrm{Pb}$ (II) ions from aqueous solutions are shown in Table 5. The $\mathrm{q}_{\max }$ value of the current study is good, relative to the other adsorbents. The differences between the reported values of $\mathrm{q}_{\max }$ can be attributed to the variances in adsorbent properties such as functional groups, porosity, and surface area. The values displayed in Table 4 indicate that GA/MNPs are an efficient adsorbent because it took only $30 \mathrm{~min}$ to remove $50 \mathrm{mg} / \mathrm{L}$ of $\mathrm{Pb}$ (II) ions from the aqueous solutions. Additionally, GA/MNPs achieved the shortest time to remove the $\mathrm{Pb}$ (II) ions. It is also obvious that the required GA/MNP mass to remove the same concentration of $\mathrm{Pb}(\mathrm{II})$ ions is less or equal to most of the reported materials except $\mathrm{Cu}_{0.5} \mathrm{Mg}_{0.5} \mathrm{Fe}_{2} \mathrm{O}_{4}$, nano-silica hollow spheres, $S$. Oleasea bark, and zeolite, as shown in Table 5. Table 5 also shows that the optimum $\mathrm{pH}$ value used in this study was in good agreement with most of the reported values. It is also clear that the maximum adsorption in most cases occurred at $\mathrm{pH}$ a range of 5.50-6.00, which is in good agreement with this study. 
Table 5. Comparison between the maximum uptake capacity and the optimum conditions for various adsorbents.

\begin{tabular}{|c|c|c|c|c|c|c|c|}
\hline \multirow[b]{2}{*}{ Material } & \multirow[b]{2}{*}{$\underset{(\mathrm{mg} / \mathrm{g})}{\mathrm{q}_{\max }}$} & \multicolumn{5}{|c|}{ Experimental Optimum Conditions } & \multirow[b]{2}{*}{ Ref. } \\
\hline & & $\mathrm{pH}$ & $\mathbf{T}(\mathrm{K})$ & $\begin{array}{c}\text { Contact } \\
\text { Time (min) }\end{array}$ & $\mathrm{C}_{\mathrm{o}}(\mathrm{mg} / \mathrm{L})$ & $\begin{array}{l}\text { Adsorbent } \\
\text { Mass (g/L) }\end{array}$ & \\
\hline $\begin{array}{l}\text { Juniperus } \\
\text { procera AC }\end{array}$ & 30.3 & 4.6 & 298 & 100 & 50 & 8 & [7] \\
\hline Apricot stone & 21.4 & 6.0 & 293 & 300 & 50 & 2 & [40] \\
\hline $\begin{array}{c}\text { Oryza sativa } \\
\text { husk }\end{array}$ & 6.1 & 8.0 & 333 & 70 & 10 & 12 & [41] \\
\hline $\begin{array}{l}\text { Nanocellulose } \\
\text { fibers }\end{array}$ & 9.4 & 5.0 & 298 & 90 & 25 & 8 & [42] \\
\hline $\begin{array}{c}\text { Polypyrrole- } \\
\text { based } \\
\text { AC }\end{array}$ & 50.0 & 5.5 & 298 & 120 & 100 & 5 & [43] \\
\hline $\mathrm{Cu}_{0.5} \mathrm{Mg}_{0.5} \mathrm{Fe}_{2} \mathrm{O}_{4}$ & 57.7 & 6.0 & 298 & 120 & 10 & 0.1 & [44] \\
\hline $\begin{array}{l}\text { Waste tire } \\
\text { rubber ash }\end{array}$ & 22.4 & 6.0 & 303 & 90 & 400 & 2 & [45] \\
\hline $\begin{array}{l}\text { Nanosilica } \\
\text { hollow } \\
\text { spheres }\end{array}$ & 200.0 & 5.0 & 333 & 40 & 300 & 0.05 & [46] \\
\hline $\begin{array}{l}\text { S. Oleasea } \\
\text { bark }\end{array}$ & 69.40 & 6.0 & 323 & 60 & 100 & 5.0 & [47] \\
\hline Zeolite & 65.8 & 5.7 & 303 & 50 & 40 & 5.0 & [48] \\
\hline GA/MNPs & 50.5 & 6.0 & 298 & 30 & 50 & 6 & This study \\
\hline
\end{tabular}

\section{Conclusions}

In this study, the adsorption characteristics of GA/MNP nanocomposite were evaluated. The investigation revealed that the prepared nanocomposite may be considered as an efficient adsorbent for lead(II) ion removal from an aqueous solution. The removal efficiency was found to be $99.3 \%$ at the optimum conditions. The removal $\%$ increased with the increase in the adsorbent dosage and the decrease in the adsorbate concentration. The maximum adsorption capacity was noticed to increase with increasing temperature, suggesting that the nature of the adsorption process is endothermic. This was further consolidated by the thermodynamic parameters calculated from experiments carried out at various temperatures. The adsorption process was found to follow the Langmuir isotherm model and pseudo-second-order kinetics. Moreover, the efficiency of the removal of $\mathrm{Pb}(\mathrm{II})$ ions was noticed to decrease slightly in the presence of interfering ions such as $\mathrm{Cr}$ (III), $\mathrm{Ni}(\mathrm{II})$, and $\mathrm{Cu}(\mathrm{II})$ ions. The composite was regenerated and used successfully at least three times to remove the $\mathrm{Pb}(\mathrm{II})$ ions from the synthetic wastewater.

Author Contributions: Conceptualization, I.H.A. and A.A.E.-Z.; Methodology, I.H.A., A.A.E.-Z., and S.M.E.; Formal analysis, A.A.E.-Z. and R.M.; Investigation, S.M.E., R.M., and M.J.; Resources, M.Z.B.-F.; Data curation, I.H.A.; Writing—original draft preparation, I.H.A.; Writing—review and editing, M.Z.B.-F.; Visualization, A.A.E.-Z. and M.J.; Supervision, I.H.A.; Project administration, M.Z.B.-F.; Funding acquisition, M.Z.B.-F. All authors have read and agreed to the published version of the manuscript.

Funding: The authors extend their appreciation to the Deanship of Scientific Research at King Khalid University for funding this work through a research group program under grant number R.G.P.1/230/41.

Data Availability Statement: Data are contained within the article.

Conflicts of Interest: The authors declare no conflict of interest. 


\section{References}

1. Malkoc, E.; Nuhoglu, Y.; Abali, Y. Cr (VI) Adsorption by Waste Acorn of Quercus ithaburensis in Fixed Beds: Prediction of Breakthrough Curves. Chem. Eng. J. 2006, 119, 61-68. [CrossRef]

2. Gebretsadik, H.; Gebrekidan, A.; Demlie, L.; Suvarapu, N. (Reviewing editor)Removal of heavy metals from aqueous solutions using Eucalyptus Camaldulensis: An alternate low cost adsorbent. Cogent Chem. 2020, 6, 1720892. [CrossRef]

3. Eltayeb, N.; Khan, A. Design and Preparation of a New and Novel Nanocomposite with CNTs and Its Sensor Applications. J. Mater. Res. Technol. 2019, 8, 2238-2246. [CrossRef]

4. Khan, A.; Asiri, A.; Khan, A.; Abdul Rub, M.; Azum, N.; Rahman, M.M.; Khan, S.B.; Alamry, K.A.; Ab Ghani, S. Sol-gel synthesis and characterization of conducting polythiophene/tin phosphate nano tetrapod composite cation-exchanger and its application as Hg (II) selective membrane electrode. J. Sol-Gel Sci. Technol. 2013, 65, 160-169. [CrossRef]

5. $\quad$ Demirbaş, Ö.; Çalımlı, M.H.; Demirkan, B.; Alma, M.H.; Nas, M.S.; Khan, A.; Asiri, A.M.; Sen, F. The Kinetic Parameters of Adsorption of Enzymes Using Carbon-Based Materials Obtained from Different Food Wastes. BioNanoScience 2019, 9, 749-757. [CrossRef]

6. Al Mesfer, M.K.; Danish, M.; Ali, I.H.; Khan, M.I. Adsorption behavior of molecular sieve $3 \AA$ and silica gel for $\mathrm{CO}_{2}$ separation: Equilibrium, breakthrough and mass transfer zone. Heat Mass Transf. 2020, 56, 3243-3259. [CrossRef]

7. Ali, I.H.; Al Mesfer, M.K.; Khan, M.I.; Danish, M.; Alghamdi, M.M. Exploring Adsorption Process of Lead (II) and Chromium (VI) Ions from Aqueous Solutions on Acid Activated Carbon Prepared from Juniperus procera Leaves. Processes 2019, 7, 217. [CrossRef]

8. Jun, B.; Her, N.; Park, C.M.; Yoon, Y. Effective removal of Pb(ii) from synthetic wastewater using Ti3C2Tx MXene. Environ. Sci. Water Res. Technol. 2020, 6, 173-180. [CrossRef]

9. Tao, Y.; Zhang, C.; Lü, T.; Zhao, H. Removal of $\mathrm{Pb}$ (II) Ions from Wastewater by Using Polyethyleneimine-Functionalized $\mathrm{Fe}_{3} \mathrm{O}_{4}$ Magnetic Nanoparticles. Appl. Sci. 2020, 10, 948. [CrossRef]

10. Greenwood, N.N.; Earnshaw, A. Chemistry of the elements. In Applied Organometallic Chemistry, 2nd ed.; Wiley \& Sons: Oxford, UK, 1998; Volume 9, p. 3365.

11. Akartasse, N.; Mejdoubi, E.; Razzouki, B.; Azzaoui, K.; Jodeh, S.; Hamed, O.; Ramdani, M.; Lamhamdi, A.; Berrabah, M.; Lahmass, I.; et al. Natural product based composite for extraction of arsenic (III) from waste water. Chem. Cent. J. 2017, 11, 33-45. [CrossRef]

12. Montenegro, M.A.; Boiero, M.L.; Valle, L.; Borsarelli, C.D. Gum Arabic: More Than an Edible Emulsifier, 1st ed.; IntechOpen: London, UK, 2012; pp. 1-26.

13. Abdul Khalil, H.P.S.; Chong, E.W.N.; Owolabi, F.A.T.; Asniza, M.; Tye, Y.Y.; Rizal, S.; Nural Fazita, M.R.; Haafiz, M.K.M.; Nurmiati, Z.; Paridah, M.T. Enhancement of basic properties of polysaccharide-based composites with organic and inorganic fillers: A review. J. Appl. Polym. Sci. 2019, 136, 47251-47270. [CrossRef]

14. Banerjee, S.S.; Chen, D.-H. Fast removal of copper ions by gum arabic modified magnetic nano-adsorbent. J. Hazard. Mater. 2007, 147, 792-799. [CrossRef] [PubMed]

15. Alzahrani, E. Gum Arabic-coated magnetic nanoparticles for methylene blue removal. Int. J. Innov. Res. Sci. Eng. Technol. 2014, 3, 15118-15129. [CrossRef]

16. Musico, Y.L.F.; Santos, C.M.; Dalida, M.L.P.; Rodrigues, D.F. Improved removal of lead (ii) from water using a polymer-based graphene oxide nanocomposite. J. Mater. Chem. A 2013, 1, 3789-3796. [CrossRef]

17. Sani, H.A.; Ahmad, M.B.; Hussein, M.Z.; Ibrahim, N.A.; Musa, A.; Saleh, T.A. Nanocomposite of ZnO with montmorillonite for removal of lead and copper ions from aqueous solutions. Process Saf. Environ. Prot. 2017, 109, 97-105. [CrossRef]

18. Alebel Gebru, K.; Das, C. Removal of $\mathrm{Pb}$ (II) and $\mathrm{Cu}$ (II) ions from wastewater using composite electrospun cellulose acetate/titanium oxide $\left(\mathrm{TiO}_{2}\right)$ adsorbent. J. Water Process. Eng. 2017, 16, 1-13. [CrossRef]

19. Williams, D.N.; Gold, K.A.; Holoman, T.R.P.; Ehrman, S.H.; Wilson, O.C., Jr. Surface modification of magnetic nanoparticles using gum Arabic. J. Nanopart. Res. 2006, 8, 749-753. [CrossRef]

20. Keshk, M.A.S.S.; El-Zahhar, A.A.; Youssef, M.S.A.; Bondock, S. Novel synthesis of flame-retardant magnetic nanoparticles/hydroxy acid cellulose-6-phosphate composite. Mater. Res. Express 2019, 6, 85310. [CrossRef]

21. Sharma, G.; Kumar, A.; Devi, K.; Sharma, S.; Naushad, M.; Ghfar, A.A.; Ahamad, T.; Stadler, F.J. Guar gum-crosslinked-Soya lecithin nanohydrogel sheets as effective adsorbent for the removal of thiophanate methyl fungicide. Int. J. Biol. Macromol. 2018, 114, 295-305. [CrossRef]

22. Farooq, M.; Sagbas, S.; Sahiner, M.; Siddiq, M.; Turk, M.; Aktas, N.; Sahiner, N. Synthesis, characterization and modification of Gum Arabic microgels for hemocompatibility and antimicrobial studies. Carbohydr. Polym. 2017, 156, 380-389. [CrossRef]

23. Keshk, S.M.A.S.; El-Zahhar, A.A.; Alsulami, Q.A.; Jaremko, M.; Bondock, S.; Heinze, T. Synthesis, characterization and ampyrone drug release behavior of magnetite nanoparticle/2,3-dialdehyde cellulose-6-phosphate composite. Cellulose 2020, $27,1603$. [CrossRef]

24. Zhuang, J.; Li, M.; Pu, Y.; Ragauskas, A.J.; Yoo, C.G. Observation of Potential Contaminants in Processed Biomass Using Fourier Transform Infrared Spectroscopy. Appl. Sci. 2020, 10, 4345. [CrossRef]

25. Aguilera, G.; Berry, C.; West, R.; Gonzalez-Monterrubio, E.; Angulo-Molina, A.; Arias-Carrion, O.; Angel Mendez-Rojas, M. Carboxymethyl cellulose coated magnetic nanoparticles transport across a human lung microvascular endothelial cell model of the blood-brain barrier. Nanoscale Adv. 2019, 2, 671-685. [CrossRef]

26. Bhakat, D.; Barik, P.; Bhattacharjee, A. Electrical conductivity behavior of Gum Arabic biopolymer-Fe ${ }_{3} \mathrm{O}_{4}$ nanocomposite. J. Phys. Chem. Solids 2018, 112, 73-97. [CrossRef] 
27. Hedayati, K.; Goodarzi, M.; Ghanbari, D. Hydrothermal Synthesis of $\mathrm{Fe}_{3} \mathrm{O}_{4}$ Nanoparticles and Flame Resistance Magnetic Poly styrene Nanocomposite. J. Nanostruct. 2017, 7, 32-39.

28. Amer, M.W.; Ahmad, R.A.; Awwad, A.M. Biosorption of Cu (II), Ni (II), Zn (II) and Pb (II) ions from aqueous solution by Sophora japonica pods powder. Int. J. Ind. Chem. 2015, 6, 67-75. [CrossRef]

29. Ouyang, D.; Zhuo, Y.; Hu, L.; Zeng, Q.; Hu, Y.; He, Z. Research on the Adsorption Behavior of Heavy Metal Ions by Porous Material Prepared with Silicate Tailings. Minerals 2019, 9, 291. [CrossRef]

30. Elkhaleefa, A.; Ali, I.H.; Brima, E.I.; Elhag, A.B.; Karama, B. Efficient Removal of Ni (II) from Aqueous Solution by Date Seeds Powder Biosorbent: Adsorption Kinetics, Isotherm and Thermodynamics. Processes 2020, 8, 1001. [CrossRef]

31. Alfaro-Cuevas-Villanueva, R.; Hidalgo-Vázquez, A.R.; Penagos, C.J.C.; Cortés-Martínez, R. Thermodynamic, Kinetic, and Equilibrium Parameters for the Removal of Lead and Cadmium from Aqueous Solutions with Calcium Alginate Beads. Sci. World J. 2014. [CrossRef]

32. Kithome, M.; Paul, J.W.; Lavkulich, L.M.; Bomke, A.A. Kinetics of Ammonium Adsorption and Desorption by the Natural Zeolite Clinoptilolite. Soil Sci. Soc. Am. J. 1998, 62, 622-629. [CrossRef]

33. Papageorgiou, S.K.; Katsaros, F.K.; Kouvelos, E.P.; Nolan, J.W.; Deit, H.L.; Kanellopoulos, N.K. Heavy metal sorption by calcium alginate beads from Laminaria digitata. J. Hazard. Mater. 2006, 137, 1765-1772. [CrossRef]

34. Ali, I.H.; Alrafai, H.A. Kinetic, isotherm and thermodynamic studies on biosorption of chromium (VI) by using activated carbon from leaves of Ficus nitida. Chem. Cent. J. 2016, 10, 36. [CrossRef] [PubMed]

35. Mehrmand, N.; Moraveji, M.K.; Parvareh, A. Adsorption of $\mathrm{Pb}(\mathrm{II}), \mathrm{Cu}(\mathrm{II})$ andNi (II) ions from aqueous solutions by functionalised henna powder (Lawsonia Inermis); isotherm, kinetic and thermodynamic studies. Int. J. Environ. Anal. Chem. 2020. [CrossRef]

36. El-Naggar, I.M.; Ahmed, S.A.; Shehata, N.E.S.; Fathy, S.M.; Shehata, A. A novel approach for the removal of lead (II) ion from wastewater using Kaolinite/Smectite natural composite adsorbent. Appl. Water Sci. 2019, 9, 7-19. [CrossRef]

37. Khan, M.I.; Almesfer, M.K.; Danish, M.; Ali, I.H.; Shoukry, H.; Patel, R.; Gardy, J.; Nizami, A.S.; Rehan, M. Potential of Saudi natural clay as an effective adsorbent in heavy metals removal from wastewater. Desalin. Water Treat. 2019, 158, 140-151. [CrossRef]

38. Ali, I.H.; Sulfab, Y. Concurrent two one-electron transfer in the oxidation of chromium (III) complexes with trans-1,2diaminocyclohexane- $N, N, N^{\prime}, N^{\prime}$-tetraacetate and diethylenetriaminepentaacetate ligands by periodate ion. Int. J. Chem. Kinet. 2012, 44, 729-735. [CrossRef]

39. Ali, I.H.; Sulfab, Y. One-step, two-electron oxidation of cis-diaquabis(1,10-phenanthroline)chromium (III) to cis-dioxobis (1,10phenanthroline) chromium (V) by periodate in aqueous acidic solutions. Int. J. Chem. Kinet. 2011, 43, 563-568. [CrossRef]

40. Mouni, L.; Merabet, D.; Bouzaza, A.; Belkhiri, L. Adsorption of Pb (II) from aqueous solutions using activated carbon developed from Apricot stone. Desalination 2011, 276, 148-153. [CrossRef]

41. Kaur, M.; Kumari, S.; Sharma, P. Removal of $\mathrm{Pb}$ (II) from aqueous solution using nanoadsorbent of Oryza sativa husk: Isotherm, kinetic and thermodynamic studies. Biotechnol. Rep. 2020, 25, e00410. [CrossRef] [PubMed]

42. Kardam, A.; Raj, K.R.; Srivastava, S.; Srivastava, M.M. Nanocellulose fibers for biosorption of cadmium, nickel, and lead ions from aqueous solution. Clean Technol. Environ. Policy 2014, 16, 385-393. [CrossRef]

43. Alghamdi, A.A.; Al-Odayni, A.-B.; Saeed, W.S.; Al-Kahtani, A.; Alharthi, F.A.; Aouak, T. Efficient Adsorption of Lead (II) from Aqueous Phase Solutions Using Polypyrrole-Based Activated Carbon. Materials 2019, 12, 2020. [CrossRef]

44. Tran, C.V.; Quang, D.V.; Thi, H.P.N.; Truong, T.N.; La, D.D. Effective Removal of Pb (II) from Aqueous Media by a New Design of $\mathrm{Cu}-\mathrm{Mg}$ Binary Ferrite. ACS Omega 2020, 5, 7298-7306. [CrossRef] [PubMed]

45. Mousavi, H.Z.; Hosseynifar, A.; Jahed, V.; Dehghani, S.A.M. Removal of lead from aqueous solution using waste tire rubber ash as an adsorbent. Braz. J. Chem. Eng. 2010, 27, 79-87. [CrossRef]

46. Manyangadze, M.; Chikuruwo, N.M.H.; Narsaiah, T.B.; Chakra, C.H.; Charis, G.; Danha, G.; Mamvura, T.A. Adsorption of lead ions from wastewater using nano silica spheres synthesized on calcium carbonate templates. Heliyon 2020, 6, e05390. [CrossRef] [PubMed]

47. Khatoon, A.; Kashif Uddin, M.; Rao, R.A.K. Adsorptive remediation of Pb (II) from aqueous media using Schleichera oleosa bark. Environ. Technol. Innov. 2018, 11, 1-14. [CrossRef]

48. He, K.; Chen, Y.; Tang, Z.; Hu, Y. Removal of heavy metal ions from aqueous solution by zeolite synthesized from flyash. Environ. Sci. Pollut. Res. 2016, 23, 2778-2788. [CrossRef] [PubMed] 